\title{
The effect of women's distance employment on the development
}

\author{
of the parenthood institution \\ Alena Fedorova ${ }^{\mathrm{a}^{*}}$, Natalia Tonkikh ${ }^{b}$, Olga Koropets ${ }^{a}$ \\ ${ }^{\mathrm{a}}$ Ural Federal University, Russian Federation \\ ${ }^{\mathrm{b}}$ Ural State University of Economics, Institution of Economics, Ural Branch of RAS, Russian \\ Federation \\ ${ }^{a}$ Ural State University of Economics, Russian Federation \\ ${ }^{*}$ Corresponding author: Alena Fedorova, Associate Professor, dekan_2002@mail.ru
}

\begin{abstract}
The article presents the results of a pilot sociological study conducted in one of the largest Russian metropolises in April 2017. The aim of the study was to determine the impact of growing women's distance employment on the institution of parenthood, as well as on women's reproductive behaviour. The practical value of further research relates to collecting a database of empirical data to assist in finding ways to solve the problem of decreasing childbirth rate, to develop mechanisms for stimulating birth rate, and to establish targeted state social and economic programmes for supporting maternity by promoting women's distance employment.
\end{abstract}

Key words: parenthood; reproductive behaviour; teleworking; distance employment; women employment

\section{Introduction}

Many aspects of the modern society are in crisis, including marital, family and parental relations. According to statistics, the birth rate per woman has shown a growing trend in recent years (from 1.691 in 2012 to 1.777 in 2015) ${ }^{1}$, but the transition of the Russian society from the narrowed to the extended type of population reproduction is only a remote prospect. Researchers note the increasing autonomy and independence in the development and functioning of the institutions of marriage, family and parenthood (A. Wagner ${ }^{2}$ ). The increase in divorce rate, in the number of common-law and guest marriages, and the number of single parents is a sign of the formation of new social attitudes and norms of behaviour. A number of researchers believe that parenting today can be regarded as a social institution (A.N. 
Schreiber $^{3}$ ). The study of its functions and structure, as well as the factors that determine the specifics of its functioning, will allow reviewing the birth rate policy, evaluating the effectiveness of the existing ways of stimulating birth rate and motivating families to have more than two children, and strengthening targeted social programmes for maternity support. In the classical theory of the labour market, women are traditionally regarded as a socially unprotected category that requires special administrative regulations and employment support programmes. According to employers, whose opinion is confirmed by the results of many studies, women's labour is much less competitive than men's labour. Employers explain their preferences for male candidates for job vacancies by women's lower labour productivity, by the fact that women are less motivated than men to achieve high results in their work, or for self-realisation at work due to their different priorities in life: family and raising children. However, the modern labour market is becoming more flexible, new forms of employment appear, such as: distance employment (working from home, exchanging information and reporting via the Internet); self-employment - producing hand-made consumer goods and selling them through social networks; freelance and others.

These forms of employment harmoniously combine with raising children. A woman with young children working remotely from home can independently adjust her work schedule and acquire financial independence. According to our working hypothesis, the further spread of distance employment can affect the functioning of the institution of parenthood and lead to the following: a steadily growing number of single-parent families (mother-children); women deciding to have children more often regardless of the presence of a husband, family or marriage; an increase in the birth rate. This hypothesis needs verification; the official statistics there are in Table 1.

Table 1 - Rate of employment and unemployment among women with children aged 0-6, \% [1]

\begin{tabular}{|c|c|c|c|c|c|c|c|c|}
\hline 2009 & 2010 & 2011 & 2012 & 2013 & 2014 & $2015^{*}$ & 2016 & Growth rate 2016/2009 \\
\hline \multicolumn{8}{|c|}{ Rate of employment } \\
\hline 62.8 & 63.3 & 63.6 & 65.1 & 63.7 & 64.0 & 64.0 & 64.9 & 103.3 \\
\hline \multicolumn{8}{|c|}{ Rate of unemployment } \\
\hline 8.4 & 7.8 & 7.5 & 6.6 & 6.4 & 5.8 & 6.4 & 6.9 & 82.1 \\
\hline
\end{tabular}

*From 2015 data include statistics for Crimea and Sevastopol

The following trend can be observed for the seven-year period: the rate of employment among women with young children has increased by 3.3\%. It should be noted that in 2016 and 2009 the Russian economy was in crisis, and the general rate of unemployment was high. Together 
with the increase in employment rate, there was a significant decrease in the unemployment rate among women with young children: by $17.9 \%$. It is difficult to clearly identify the factors that influenced these trends: it is possible that the spread of women's distance employment made its contribution. In our study, we aim to confirm or refute the influence of the development of distance employment on the institution of parenthood, or rather on women's motivation to have children.

\section{Method and sample}

A survey questionnaire was used as the main research method. The research object and the general population are women of childbearing age. During the first stage of the research, the author developed and tested the sociological tool (questionnaire). The pilot research was conducted in Yekaterinburg in April 2017. The sample of the respondents was formed randomly. The age distribution of women in the municipality, the number of children they have and their marital status were not taken into account, as the objectives of the pilot survey were: obtaining preliminary data on the feasibility of further research and planning its next steps; approbation of the questionnaire (checking its quality); determining the size and structure of the sample for the future study.

80 women of childbearing age were surveyed. The respondents were asked to evaluate the clarity of the questions in order to improve the questionnaire. The age structure of the pilot research sample: $18-24$ - 81\%, 25-29 - 7\%, 30-34 - 2\%, 35-39 - 3\%, 40-45 - 7\%. Respondents' answers to the question “Are you married?”» were distributed as follows: $29 \%$ "Yes”, and 71\% - "No". Almost a quarter of respondents have children (24\%). The fact that unmarried women prevail is explained by their age: the respondents were mostly aged from 18 to 24; the average age when women get married has increased and a shift towards the European model of family behaviour has occurred.

\section{Results and discussion}

In the subset of women with children, the proportion of women with preschool children was 57\%: 71\% have one child, the rest have two children. When answering the question "Who is the head of your family?" women with children indicated themselves only if they were not married (21\% of the number of women with children). $64 \%$ of married women with children traditionally answered that their husband is the head; the remaining $36 \%$ indicated that all decisions in their family are taken together, nobody can be considered the head of the family. 
The respondents' answers to the question about their employment are presented in Table 2.

Table 2 - Respondents' answers about their employment, \%

\begin{tabular}{|l|c|c|c|}
\hline \multirow{2}{*}{ Answer options } & \multirow{2}{*}{ Total } & \multicolumn{2}{c|}{ In the subset of women } \\
\cline { 3 - 4 } & & with children & without children \\
\hline "Housewife" & 12 & 50 & 0 \\
\hline "In employment (full-time)" & 56 & 36 & 62 \\
\hline "In employment (part-time)" & 19 & 7 & 22 \\
\hline "Out of employment" & 14 & 7 & 16 \\
\hline In total & 100 & 100 & 100 \\
\hline
\end{tabular}

The results obtained revealed the influence of the marital status and the number of children on women's decision to work (not to work). When asked directly: "Does your decision depend on whether or not you have children?”, about a third of the respondents answered affirmatively. More than half of the women with children are currently not working, $7 \%$ are working part-time. Childless women are mostly unmarried and work full-time, although the number of those in part-time employment is quite high (22\%). Of the working women with children, $17 \%$ work from home; the rate of distance employment in the subset of childless women was approximately the same.

The distribution of the answers to the question "Would you like to combine work with household duties and raising children?” was quite interesting (Table 3).

Table 3 - Respondents’ answers about their readiness to combine work and raising children, \%

\begin{tabular}{|l|c|c|c|}
\hline \multirow{2}{*}{ Answer options } & \multirow{2}{*}{ Total } & \multicolumn{2}{c|}{ In the subset of women } \\
\cline { 3 - 4 } & & with children & without children \\
\hline "Yes" & 53 & 71 & 47 \\
\hline "No" & 24 & 14 & 27 \\
\hline "I don't know" & 24 & 14 & 27 \\
\hline In total & 100 & 100 & 100 \\
\hline
\end{tabular}

Childless women, mostly working, would be less willing to work if they had children than women who already have children. Some of the women with children are likely to be not fully satisfied with their life situation, as there is a significant difference between their desire to work and the actual level of employment in this group of respondents: $71 \%$ want to work, and only $43 \%$ are actually employed. It is these women that will most likely be interested in distance employment, but not all women with children have the required competences to work remotely. 
In the pilot survey, a fairly traditional question was asked to find out the reproductive intentions of the population: the desired number of children (the number of children a woman would prefer to have, based on her own inclinations, without taking into account specific life circumstances). The results are presented below (Table 4).

Table 4 - Respondents’ answers about the desired number of children, \%

\begin{tabular}{|l|c|c|c|}
\hline \multicolumn{1}{|c|}{ Answer options } & \multirow{2}{*}{ Total } & \multicolumn{2}{c|}{ In the subset of women } \\
\cline { 3 - 4 } & & with children & without children \\
\hline “I don't want to have children” & 2 & 0 & 2 \\
\hline "I would like to have 1 child” & 2 & 0 & 2 \\
\hline "I would like to have 2 children” & 64 & 57 & 67 \\
\hline "I would like to have 3 children” & 22 & 21 & 22 \\
\hline "I would like to have more than 3 children” & 2 & 0 & 2 \\
\hline "I don't know” & 8 & 22 & 4 \\
\hline In total & 100 & 100 & 100 \\
\hline
\end{tabular}

The obtained data correlate with the published results of the All-Russian Centre for Public Opinion Research study, conducted during the period from 1991 to $2000{ }^{4}$ It can be concluded that Russian women's reproductive intentions are stable.

In the pilot project, women were asked the question: "On what conditions would you like to have three children (or more)?”. The structure of the answers is presented below (Table 5).

Table 5 - Subjective conditions for having more than 2 children, \%

\begin{tabular}{|l|c|c|c|}
\hline \multicolumn{1}{|c|}{ Answer options } & \multirow{2}{*}{ Total } & \multicolumn{2}{c|}{ In the subset of women } \\
\cline { 3 - 4 } & & with children & without children \\
\hline "On no condition“ & 27 & 29 & 27 \\
\hline $\begin{array}{l}\text { "If I have a husband who is the breadearner (being a } \\
\text { housewife)" }\end{array}$ & 42 & 21 & 49 \\
\hline "If I have an opportunity to be employed part-time” & 10 & 7 & 11 \\
\hline "If I have an opportunity to work from home (telework)" & 14 & 21 & 11 \\
\hline "I don't know" & 7 & 21 & 2 \\
\hline In total & 100 & 100 & 100 \\
\hline
\end{tabular}

More than a third of those surveyed are not ready to have many children on any condition. However, $42 \%$ allow for the possibility of having more than three children if their husband provides for the family and they become housewives. Women with children have more realistic views of family life: twice as little of them rely on their husbands as breadwinners compared to unmarried women without children. Women with children mostly count on themselves and mention non-standard employment as a condition for deciding to have many children: part-time employment (7\%) or distance employment (teleworking - 21\%). It should 
be noted that compared to women without children, twice as many mothers selected distance employment as a condition for having three and more children. Our hypothesis about the possible influence of growing distance employment on the changes in the institution of parenthood was confirmed.

The influence of socio-economic factors, the possibility of combining work and raising children in particular, on the institution of parenthood is confirmed by the answers to the question "On what conditions would you decide to have a child without the support of a husband (the child's father)?", addressed to unmarried women without children. $20 \%$ of the women surveyed indicated the "opportunity to work from home during maternity leave" as a condition for deciding to raise a child without being married.

\section{Conclusions}

Thus, the pilot project confirmed the need to continue research into the nature and extent of the impact of growing distance employment among women on the institution of parenthood, on changing women's reproductive behaviour. The practical implications of further research into the topic are related to the development of mechanisms for stimulating birth rate, of targeted state social and economic programmes for supporting maternity by means of promoting women's distance employment.

\section{Acknowledgements}

The work was supported by Act 211 Government of the Russian Federation, contract № 02.A03.21.0006

\section{References / Literatura}

1. URL: $\quad$ http://www.gks.ru/wps/wcm/connect/rosstat_main/rosstat/ru/statistics/ population/motherhood/\# (22.7.2017)

2. A. Wagner, Prekarization and atypical employment of women and men in Germany and Europe. URL: http://www.library.fes.de/pdf-files/bueros/ukraine/10924.pdf (14.2.2017)

3. A.N. Schreiber, Social factors of parental activity in municipalities of Altai Krai, The Bulletin of the Altai state agricultural university. Vol. 3 (113), 2014, str. 175-180.

4. V. Bodrova, How much children Russians want to have? Demoskop Weekle. Vol. 8182. URL: http://demoscope.ru/weekly/2002/081/tema01.php (12.2.2017) 